\title{
EVALUASI PENGARUH KESESUAIAN TERAPI HIPERTENSI DENGAN GUIDELINE JNC 7 TERHADAP TERCAPAINYA TARGET TEKANAN DARAH PASIEN DI RS PANTI WALUYO SURAKARTA PERIODE JANUARI-DESEMBER 2013
}

\section{EVALUATION OF APPPROPRIATELY THERAPY HYPERTENSION EFFECT BY JNC 7 GUIDELINE TO ACHIEVE TARGET BLOOD PRESSURE OF PATIENTS IN PANTI WALUYO HOSPITAL SURAKARTA PERIOD JANUARY-DECEMBER 2013}

\author{
1)Truly Dian Anggraini, 2)Ika Puspita Sari, 3)Probosuseno \\ truly_24hours@yahoo.co.id \\ 1)2)Program studi Farmasi Klinik, Pasca Sarjana Fakultas Farmasi Universitas Gadjah Mada \\ 3)RSUP Dr. Sardjito, Yogyakarta
}

\section{Intisari}

Hipertensi merupakan masalah utama kesehatan publik di seluruh dunia dan merupakan faktor resiko penyakit kardiovaskuler tersering. Prevalensi hipertensi pada penduduk umur 18 tahun ke atas sebesar 29,8\%. Data epidemiologi menunjukkan bahwa peningkatan tekanan darah akan meningkatkan kejadian kardiovaskuler, sehingga hipertensi harus diobati dengan tepat. Penelitian ini bertujuan untuk mengetahui pengaruh kesesuaian terapi hipertensi dengan guideline JNC 7 terhadap tercapainya target tekanan darah pasien di RS Panti Waluyo Surakarta periode Januari-Desember 2013. Penelitian ini merupakan penelitian cohort dimana pengambilan data dilakukan secara retrospektif dari catatan rekam medik pasien hipertensi rawat inap. Sebanyak 116 sampel diperoleh, pola antihipertensi serta kesesuaian terapi hipertensi dengan guideline JNC 7 dianalisis secara diskriptif, pengaruh kesesuaian terapi hipertensi dengan guideline JNC 7 terhadap tercapainya target tekanan darah pasien dianalisis secara statistik menggunakan Chi-square. Hasil penelitian, 50 pasien mendapatkan terapi hipertensi yang sesuai dan 66 pasien mendapatkan terapi hipertensi yang tidak sesuai dengan guideline JNC 7. Pola obat antihipertensi, 38 pasien diresepkan obat antihipertensi tunggal, 34 pasien kombinasi 2 obat antihipertensi, selebihnya pasien diresepkan lebih dari 2 antihipertensi. Outcome terapi, 66\% dari 50 pasien yang mendapatkan terapi hipertensi yang sesuai mampu mencapai target tekanan darah, 47\% dari 66 pasien yang mendapatkan terapi hipertensi yang tidak sesuai mampu mencapai target tekanan darah. Ada hubungan yang signifikan antara kesesuaian terapi hipertensi dengan guideline JNC 7 terhadap ketercapaian target tekanan darah $(p<0,05)$.

Kata kunci: Hipertensi, Kesesuaian Terapi, Target Tekanan Darah

\begin{abstract}
Hypertension is a major public health problem worldwide and is the most common risk factor for cardiovascular disease. The prevalence of hypertension in the population aged 18 years and above at $29.8 \%$. Epidemiological data indicates that an increase of blood pressure would improve cardiovascular events. Therefore, hypertension should be treated appropriately by controlling blood pressure. This research aims to evaluate the effect of appropriateness of therapy hypertension based on JNC7 guideline in order to gain targeted blood pressure in RS Panti Waluyo Surakarta during January-December 2013. This study conducted using cohort retrospectively in inpatients medical record in RS Panti Waluyo Surakarta. A total of 116 samples were analyzed with descriptive-analytic method. Both monotherapy and combination of anti-hypertension drug were analyzed with JNC 7 guideline while the target blood pressure were statistically analized using Chi-square test. This research
\end{abstract}


result showed that 50 patients exhibited the appropriate anti-hypertension therapy, while 66 patients showed the inappropriate anti-hypertension therapy. The pattern of anti-hypertension was that 38 patients prescribed single anti-hypertension medicine, 34 patients prescribed combination of 2 anti-hypertension medicine. Like the patients in appropriate group (66\%), there were (47\%) patients in inappropriate group could achive the target of blood pressure. In conclusion, there is a significant relationship between appropriateness of anti-hypertension use and target blood pressure ( $p$ <0.05).

\section{Keywords: Hypertension, Appropriateness of Therapy, Targeted Blood Pressure}

\section{Pendahuluan}

Hipertensi merupakan masalah kesehatan publik utama di seluruh dunia dan merupakan faktor resiko penyakit kardiovaskuler tersering, serta belum terkontrol optimal di seluruh dunia. Namun, hipertensi dapat dicegah dan penanganan dengan efektif dapat menurunkan resiko stroke dan serangan jantung (Kaplan dan Victor, 2009). Berdasarkan JNC 7 hipertensi merupakan suatu kondisi dimana tekanan darah sistolik $\geq 140 \mathrm{mmHg}$ atau tekanan darah diastolik $\geq 90 \mathrm{mmHg}$ (Chobanian dkk., 2003).

Penelitian epidemiologi menunjukkan bahwa resiko kerusakan ginjal, jantung, dan otak berkaitan secara langsung dengan derajat peningkatan tekanan darah. Bahkan hipertensi ringan (tekanan darah 140/90 $\mathrm{mmHg}$ ) akhirnya akan meningkatkan resiko kerusakan organ sasaran. Data epidemiologi menunjukkan bahwa peningkatan TD sistolik, dan atau TD diastolik akan meningkatkan kejadian kardiovaskuler. Semakin tinggi tekanan darah, semakin tinggi resiko terjadinya penyakit jantung koroner (PJK), gagal jantung, stroke, atau gagal ginjal. Oleh karena itu hipertensi harus diobati dengan tepat dan selalu dikontrol tekanan darahnya (Kabo, 2010).

$$
\text { Health People } 2010 \text { for Hypertension }
$$
menganjurkan perlunya pendekatan yang lebih komprehensif dan intensif guna mencapai pengontrolan tekanan darah secara optimal. Maka untuk mencapai tujuan tersebut, diperlukan partisipasi aktif para sejawat apoteker yang melaksanakan praktek profesinya pada setiap tempat pelayanan kesehatan. Apoteker dapat bekerja sama dengan dokter dalam memberikan edukasi ke pasien mengenai hipertensi, memonitor respon pasien melalui farmasi komunitas, adherence terhadap terapi obat dan non obat, mendeteksi dan mengenali secara dini reaksi efek samping, serta mencegah dan atau memecahkan masalah yang berkaitan dengan pemberian obat (Departemen Kesehatan RI, 2006). Berdasarkan latar belakang diatas, maka penulis memandang perlu untuk diadakan evaluasi mengenai pengaruh kesesuaian terapi hipertensi dengan guideline JNC 7 terhadap tercapainya target tekanan darah pada pasien hipertensi di RS Panti Waluyo Surakarta.
Metode Penelitian

Penelitian ini termasuk jenis penelitian cohort dimana pengambilan data dilakukan secara retrospektif dari catatan rekam medik pasien hipertensi di instalasi rawat inap di RS Panti Waluyo Surakarta selama bulan Januari sampai Desember 2013, kemudian peneliti mencocokkan obat antihipertensi yang diterima pasien dengan JNC 7 dan tekanan darah ketika pasien akan pulang dengan target tekanan darah seperti yang ditetapkan oleh JNC 7.

\section{Subjek Penelitian}

Pasien hipertensi dengan atau tanpa penyakit penyerta (Diabetes melitus, hiperlipidemia, gagal ginjal kronik) dewasa yang berusia $\geq 18$ tahun baik laki-laki maupun perempuan, yang mendapat terapi hipertensi baik yang sesuai maupun yang tidak sesuai dengan guideline JNC 7 yang menjalani rawat inap di RS Panti Waluyo Surakarta pada periode bulan Januari-Desember 2013.

\section{Instrumen Penelitian}

Form pengambilan data, digunakan untuk mengumpulkan data-data yang diambil dari buku medical record atau status pasien yang meliputi nama, umur, jenis kelamin, data diagnosis rumah sakit, data-data laboratorium dan medikasi yang diterima pasien.

\section{Jalannya Penelitian}

Mencatat Data pasien hipetensi rawat inap yang diperoleh dari catatan rekam medik pasien hipertensi di instalasi rawat inap di RS Panti Waluyo Surakarta selama bulan Januari sampai Desember 2013. Setelah itu dilakukan analisis dari data yang diperoleh, yaitu : Mengidentifikasi karakteristik pasien antihipertensi di instalasi rawat inap RS Panti Waluyo Surakarta periode Januari-Desember 2013, mengidentifikasi pola pengobatan antihipertensi di instalasi rawat inap RS Panti Waluyo Surakarta periode Januari-Desember 2013, serta menganalisis pengaruh kesesuaian terapi hipertensi dengan guideline JNC 7 terhadap tercapainya target tekanan darah pasien hipertensi di instalasi rawat inap RS Panti Waluyo Surakarta periode Januari-Desember 2013. 


\section{Hasil dan Pembahasan}

Penelitian dilakukan dengan membaca catatan rekam medik pasien hipertensi rawat inap di RS Panti Waluyo Surakarta periode Januari-Desember 2013, jumlah pasien hipertensi pada rentang waktu tersebut yang memenuhi kriteria inklusi untuk masuk dalam penelitian ini sebanyak 116 pasien. Pada penelitian ini, pasien dikelompokkan salah satunya berdasarkan karakteristik pasien, Karakteristik pasien dalam penelitian ini dikelompokkan berdasarkan jenis kelamin, umur, derajat hipertensi dan penyakit penyerta.

Pada penelitian ini dari 116 pasien diperoleh hasil bahwa perempuan lebih banyak menderita hipertensi daripada laki-laki. Pasien perempuan penderita hipertensi sebanyak 69 pasien atau sebesar $59,5 \%$ sedangkan pasien laki-laki penderita hipertensi sebanyak 47 pasien atau sebesar 40,5\%. Sehingga dapat dikatakan penderita hipertensi di Rumah Sakit Panti Waluyo Surakarta pada periode bulan JanuariDesember 2013 lebih didominasi oleh pasien perempuan. Gambaran karakteristik pasien hipertensi dilihat dari usia adalah $62,1 \%$ pasien masuk dalam kategori pasien dewasa yang berusia 18-64 tahun, dan $37,9 \%$ pasien berusia $\geq 65$ tahun. Hasil penelitian menunjukkan bahwa $76,7 \%$ pasien hipertensi di RS Panti Waluyo Surakarta periode Januari-Desember 2013 masuk ke dalam kategori hipertensi derajat 2, dan $23,28 \%$ sisanya masuk ke dalam kategori hipertensi derajat 1 .
Gambaran karakteristik pasien dilihat dari ada tidaknya penyakit penyerta adalah dari 116 pasien, 80 pasien $(69 \%)$ diantaranya tanpa adanya compelling indication dan 36 pasien (31\%) disertai dengan penyakit penyerta. Jenis compelling indication pada pasien hipertensi di RS Panti Waluyo Peride JanuariDesember 2013 yang paling banyak adalah DM dan stroke masing-masing sebesar $42 \%$, kemudian diikuti CKD dan penyakit jantung masing-masing sebesar $8,3 \%$.

Data rekam medis 116 pasien hipertensi menunjukkan penggunaan jenis obat antihipertensi tunggal sebanyak 31,9\%, kombinasi 2 antihipertensi sebesar 29,3\%, kombinasi 3 antihipertensi 18,1\% dan kombinasi 4 antihipertensi sebesar 8,6\%. Dari penggunaan antihipertensi secara tunggal, obat antihipertensi yang paling banyak digunakan adalah dari golongan CCB sebanyak 16,4\%, sedangkan penggunaan 2 kombinasi antihipertensi yang banyak digunakan adalah kombinasi CCB+ACEI yaitu sebesar 7,8\%. Kombinasi 3 obat antihipertensi yang paling banyak digunakan adalah kombinasi $\mathrm{CCB}+$ Diuretik+ARB, sedangkan kombinasi 4 antihipertensi yang paling banyak digunakan adalah kombinasi diuretik $+\mathrm{CCB}+\mathrm{BB}+\mathrm{ARB}$, diuretik + $\mathrm{CCB}+\mathrm{BB}+\mathrm{ACEI}$, serta $\mathrm{CCB}+\mathrm{BB}+\mathrm{ARB}+\alpha$ masing-masing sebesar $1,7 \%$. Dari semua pola penggunaan antihipertensi baik tunggal maupun kombinasi 2 sampai 4 antihipertensi, selalu menggunakan antihipertensi dari golongan CCB.

Tabel 1. Hubungan Kesesuaian Terapi Hipertensi dengan Guideline terhadap Outcome Terapi

\begin{tabular}{ccccc}
\hline \multirow{2}{*}{ Kesesuaian } & \multicolumn{2}{c}{ Target Tekanan Darah } & Total & OR $(95 \%$ CI $)$ \\
\cline { 2 - 4 } & Tercapai & Tidak Tercapai & & \\
\hline Sesuai & 33 & 17 & 50 & \multirow{2}{*}{2,192} \\
\hline Tidak Sesuai & 31 & 35 & 66 & $(1,062-4,682)$ \\
\hline Total & 64 & 52 & 116 & \\
\hline$p$-value & & 0,041 & &
\end{tabular}

Hasil uji Chi-square menunjukkan bahwa ada hubungan yang signifikan antara kesesuaian terapi hipertensi dengan guideline JNC 7 terhadap ketercapaian target tekanan darah $(p<0,05)$. Dilihat dari nilai Old Ratio (OR) dapat disimpulkan bahwa kelompok pasien yang mendapat terapi hipertensi sesuai dengan guideline JNC 7 memiliki kemungkinan mencapai target tekanan darah 2 kali lebih besar dibandingkan kelompok yang mendapat terapi hipertensi yang tidak sesuai dengan guideline JNC 7, dimana hasil ini juga signifikan secara statistik $(95 \%$ $\mathrm{CI})$.

\section{Keterbatasan Penelitian}

Walaupun sudah diupayakan sebaik mungkin, penelitian ini masih terdapat banyak keterbatasan, antara lain Metode penelitian menggunakan metode retrospektif, sehingga peneliti hanya dapat mengakses informasi sebatas yang tertulis di rekam medik tanpa bisa melakukan konfirmasi kepada dokter maupun perawat yang merawat pasien, serta pasien yang bersangkutan. Catatan rekam medis yang kurang lengkap (tinggi badan, berat badan, riwayat penyakit sebelumnya, riwayat pengobatan sebelumnya), sehingga mempersulit peneliti untuk mendiskripsikan kondisi pasien, serta pola pengobatan antihipertensi yang diterima pasien serta tidak adanya lembar rekonsiliasi obat, dimana pada lembar rekonsiliasi oat dapat diketahui obat apa yang diteruskan, diganti, maupun dinaikkan atau diturunkan dosisnya, dan ditemukan tidaknya pasien mengkonsumsi obat herbal atau obat antihipertensi lain diluar yang diresepkan oleh dokter. 


\section{Simpulan}

Pola penggunaan antihipertensi pada pasien rawat inap di RS Panti Waluyo Surakarta periode Januari-Desember 2013 adalah pasien yang mendapat antihipertensi tunggal sebesar $31,9 \%$, pasien yang menerima kombinasi 2 antihipertensi sebesar 29,3\%, pasien yang menerima kombinasi 3 antihipertensi sebesar $18,1 \%$, dan pasien yang menerima kombinasi 4 antihipertensi sebesar 8,6\%. Dari 116 pasien hipertensi rawat inap di RS Panti Waluyo Surakarta periode Januari-Desember 2013, 50 pasien (43\%) mendapatkan terapi hipertensi yang sesuai dengan guideline JNC 7 dan 66 pasien (57\%) mendapatkan terapi antihipertensi yang tidak sesuai dengan guideline JNC 7. Pasien yang mendapat terapi hipertensi sesuai dengan guideline JNC 7 memiliki kemungkinan mencapai target tekanan darah 2 kali lebih besar dibandingkan kelompok yang mendapat terapi hipertensi yang tidak sesuai dengan guideline JNC 7.

\section{Ucapan Terimakasih}

Peneliti mengucapkan terima kasih kepada RS Panti Waluyo Surakarta yang telah memberikan izin untuk melakukan penelitian dan semua pihak yang turut membantu terselesaikannya penelitian ini.

\section{Daftar Pustaka}

Chobanian, A., Bakris, G., Black, H., Chusman, W., Green, I., Izzo, J., 2003. JNC VII Express : The Seventh Report of the Joint National Commite on Prevention, Detection, Evaluation and Treatment of High Blood Pressure. U.S Department of Health and Human Services.

Departemen Kesehatan RI, 2006. Pharmaceutical Care Untuk Penyakit Hipertensi. Departemen Kesehatan RI, Jakarta.

Kabo, P., 2010. Bagaimana Menggunakan Obat-Obat Kardiovaskuler Secara Rasional. Fakultas Kedokteran Universitas Indonesia.

Kaplan, N.M. dan Victor, R.G., 2009. Kaplan's Clinical Hypertension, Tenth edition. ed. LWW, Philadelphia. 